\title{
Isolation and characterization of Bacillus megaterium isolates from dead pentatomids and their insecticidal activity to Palomena prasina nymphs
}

\author{
Hasan Murat AKSOY ${ }^{1}$, Celal TUNCER ${ }^{1}$, Islam SARUHAN ${ }^{1}$, Ismail ERPER ${ }^{1}$, Murat OZTURK ${ }^{1}$, Izzet AKCA ${ }^{1}$ \\ ${ }^{1}$ Ondokuz Mayis University, Faculty of Agriculture, Department of Plant Protection, SAMSUN
}

Alınış tarihi: 19 Aralık 2017, Kabul tarihi 06 Nisan 2018

Sorumlu yazar: İslam SARUHAN, e-posta:isaruhan@omu.edu.tr

\begin{abstract}
Bacillus megaterium isolates, were demonstrated to be efficient biocontrol agents against the green shield bug (Palomena prasina L., Heteroptera: Pentatomidae). Firstly hazelnut orchards were surveyed and four B. megaterium isolates were obtained from $P$. prasina. The morphological, physiological and biochemical characteristics of $B$. megaterium isolates were determined according to the standardized methodology. Additionally $16 \mathrm{~S}$ rRNA gene sequence analyse was performed to determine the isolates. Analysis of the 16S rRNA gene confirmed that isolates Sa-1, Sa-5, SAk-2 and SAkc-19 are B. megaterium, with $100 \%$ sequence homology to the type strains of $B$. megaterium. Effectiveness of these isolates was tested against $P$. prasina nymphs in laboratory, at $25 \pm 1^{\circ} \mathrm{C}$ and $70 \pm 5$ RH. Isolates were bioassayed against nymphs and dead individuals were counted daily, following a 12 days lasting treatment. Lethal time ( $\mathrm{LT}_{50}$ and $\mathrm{LT}_{90}$ ) values of $B$. megaterium isolates were calculated. $\mathrm{LT}_{50}$ values of the two most active isolates were 1.91 and 11.18 days. The highest mortality rate was $98 \%$ obtained with the treatment of SAkc-2 isolates at concentrations of $10^{8} \mathrm{cfu} \mathrm{ml}^{-1}$ on the $12^{\text {th }}$ day of post treatment.
\end{abstract}

Key words: Bacillus megaterium, Palomena prasina, biological control, entomopathogen
Ölü pentatomidlerden Bacillus megaterium izolatlarının izolasyonu, karekterizasyonu ve Palomena prasina nimflerine insektisital etkisi

Öz

Bu çalışma, Bacillus megaterium izolatlarının findık kokarcasina (Palomena prasina L., Heteroptera: Pentatomidae) karşı etkin biyokontrol ajanları olduğu gösterilmiştir. Öncelikle fındık bahçelerinde survey yapılarak, $P$. prasina'dan dört Bacillus megaterium izolatı elde edilmiştir. B. megaterium izolatlarının morfolojik, fizyolojik ve biyokimyasal özellikleri standart tanı yöntemlerine göre belirlenmiştir. Ayrıca izolatların tanısı için 16S rRNA gen dizi analizi yapılmıştır. 16S rRNA geninin analizi sonucu; Sa-1, Sa-5, SAk-2 ve SAkc-19 izolatlarının $B$. megaterium olduğu, tip ırkları ile \% 100 dizi benzerliği göstermesi ile doğrulanmıștır. $\mathrm{Bu}$ izolatların etkinliği, laboratuarda $25 \pm 1{ }^{\circ} \mathrm{C}$ ve $70 \pm 5$ RH'de $P$. prasina nimflerine karşı denenmiştir. İzolatlar, nimflere karşı biyolojik olarak test edilmiş ve son uygulamadan 12 gün sonra ölen bireyler günlük olarak sayılmıștır. B. megaterium izolatlarının Lethal zaman değerleri (LT ${ }_{50}$ ve $\mathrm{LT}_{90}$ ) hesaplanmıștır. En aktif iki izolatın $\mathrm{LT}_{50}$ değerleri 1.91 ve 11.18 gün olarak belirlenmiştir. En yüksek ölüm oranı, SAkc-2 izolatının $10^{8} \quad \mathrm{cfu} \mathrm{ml}^{-1}$ konsantrasyon uygulanması ile 12 . günde $\% 98$ olarak elde edilmiştir.

Anahtar kelimeler: Bacillus megaterium, Palomena prasina, biyolojik mücadele, entomopatojen 


\section{Introduction}

Turkey is the largest producer of hazelnut in the world. The country, account for around 75 percent of total global hazelnut production. The total area of hazelnut orhards is currently around 618000 tons a year and 2.3 billion US dollars yearly from hazelnut exports in 2014 in Turkey (Tuncer et al., 2002; Anonymous, 2016a, b).

Several insect pests infest hazelnut orchards. Among these insect pests are some pentatomids which effect on hazelnut kernel quality (Tavella et al., 2001; Tuncer et al., 2004; Tuncer et al., 2009). Feeding of pentatomids causes empty nuts during early season and kernel damage during later period. Kernels damaged by pentatomids lost their shape and taste bitter. Among pentatomids, the predominant species is the green shield bug, Palomena prasina L., (Heteroptera: Pentatomidae) with $85 \%$ prevalence in hazelnut orchards of Black Sea region of Turkey (Tuncer et al., 2005). The public concern over the dangerous effects of insecticides on the living organisms and atmosphere has enhanced the search of safer and ecologically friendly biological control alternatives. One of alternative control may suggestion an additional technique for the management of $P$. prasina. Few antagonistic microorganisms are positively applied to control pests in contaminated soil. These microorganisms consist of Bacillus species, B. thuringiensis (Bt), Lysinibacillus sphaericus (Ls) and B. megaterium $(\mathrm{Bm})$. The usage of $\mathrm{Bm}$, which can produce insecticidal metabolites, also deliberated to be a promising tool for controlling the chemical pests (Aksoy and Ozman-Sullivan, 2008). It is also a potential biological control agent of nematodes (Padgham and Sikora, 2007; Huang et al., 2010). Bm is a Gram-positive, mostly aerobic spore-forming bacterium found broadly in diverse habitats from soil to seawater, river, sea food and salt lake (Gu et al., 2007; Patricia et al., 2007). Even though there have been various researches on microorganism as a possible bacterial control agent (Sezen et al., 2004; Buresova et al., 2006; Gokce et al., 2010; Ozsahin et al., 2014), none have used on B. megaterium against P. prasina.

The aim of this study was to obtain bacterial isolates from dead pentatomids in hazelnut orchards in Düzce, Samsun, Giresun and Ordu provinces in Black Sea region of Turkey, to characterize these isolates by molecular methods and to determine their insecticidal activity against $P$. prasina nymphs. This is the first study investigating the effects of $B$. megaterium against $P$. prasina.

\section{Materials and Methods}

\section{Insect culture}

Fourth stage nymphs of $P$. prasina were used in bioassays. The nymphs were collected from different hazelnuts orchards by beating-sheet method during July in Samsun province. The insects were conserved in climate chamber with $25 \pm 1{ }^{\circ} \mathrm{C}, 70 \pm 5$ relative humidity and photoperiodic lighting (16 hours of light: 8 hours of dark). After the bugs were transferred to the laboratory conditions, the insect culture was fed with fresh bean pods (Phaseolus vulgaris) and food was changed daily basis.

\section{Bacterial isolation}

Bacillus isolates were isolated from dead male and female $P$. prasina individuals found in hazelnut orchards in Giresun, Düzce, Ordu and Samsun cities, located in Black Sea region of Turkey. These orchards had not been previously treated with any Bacillus biopesticide. The collected samples were kept at about $4^{\circ} \mathrm{C}$ in the refrigerator until they are used for bacterial isolation. To eliminate external contamination, dead $P$. prasina male and female individuals were disinfected in $1 \% \mathrm{NaOCl}$ within 3 min. Thereafter, the samples were kept several times in sterile distilled water and moved aseptically into a sterile mortar and macerated with a sterile pestle. The macerate was placed in $1.5 \mathrm{ml}$ of sterile distilled water. The suspension was then heated to $75^{\circ} \mathrm{C}$ for 10-15 min, and diluted in the ratios of $1 \times 10^{-2}$ and $1 \times 10^{-4}$. The dilutions were streaked on nutrient agar and the plates were incubated at $30^{\circ} \mathrm{C}$ for $48 \mathrm{~h}$ (Cavados et al., 2001). The colony characteristic are observed for selection of candidate isolates.

\section{Biochemical characteristics}

The biochemical characteristics, morphological and physiological of $\mathrm{Bm}$ isolates were identified based on the standardized methods recommended in Bergey's Manual of Systematic Bacteriology (Logan and Vos, 2009).

\section{S rRNA gene sequencing}

The bacterial total genomic DNA was extracted from bacterial suspensions (after $12 \mathrm{~h}$ incubation in LB) using Qiagen DNA extraction kit and DNA concentration was standardized at about $50 \mathrm{ng} / \mu \mathrm{l}$ prior to performing PCR assay. Four bacterial isolates were sequenced for the 16S rRNA region. 16S rRNA gene was amplified in $50 \mu$ volume as described for PCR tests above, using the universal 
primers 27F (AGAGTTTGATC(AC)TGGCTCAG; positions 8 to 27 and 1492R (ACGGTTACCT TGTTACGACTT; positions 1508 to 1492, (Weisburg et al., 1991). Amplifications of the 16S rRNA fragments were achieved in a final volume of $50 \mu \mathrm{l}$ with $5 \mu \mathrm{l}$ of $10 \times$ PCR buffer (Qiagen), $1.5 \mathrm{mM} \mathrm{MgCl2,}$ $1 \mu \mathrm{l}$ PCR Nucleotide Mix Plus (Roche), $0.2 \mu \mathrm{M}$ of each primer, $1.25 \mathrm{U}$ Taq polymerase (250 U HotStarTaq DNA Polymerase, Qiagen) and $3 \mu$ l of template DNA. Reactions were used in a Bio-Rad T100 Thermal Cycler. The PCR conditions used were $15 \mathrm{~min}$ at $94^{\circ} \mathrm{C}, 35$ cycles of $30 \mathrm{~s}$ at $94^{\circ} \mathrm{C}, 1 \mathrm{~min}$ at $52^{\circ} \mathrm{C}$ and 90 $\mathrm{s}$ at $72^{\circ} \mathrm{C}$, followed by a final extension at $72^{\circ} \mathrm{C}$ for 7 min. Sequencing for PCR results of the selected strains was performed in both directions and the sequencing reactions were carried out by the Medsantek Company, Turkey. The chromas Pro software (Technelysium Pty Ltd, Qld, Australia) was used for editing and regenerating the obtained sequences. Resulted partial 16S rRNA fragment sequences of Bacillus megaterium were searched in GenBank database with available sequences using nucleotide-nucleotide Basic Local Alignment Search Tool (BLAST) for nucleotides alignments to perform phylogenetic analysis. The phylogram was produced by the maximum likelihood programme (Tamura et al., 2013).

\section{Insecticidal activity}

Fourth stage nymphs of $P$. prasina were placed in $1 \mathrm{~L}$ plastic ice-cream cups (sterilized by ethanol) containing two 5-6 $\mathrm{cm}$ long fresh bean pods. Ten $4^{\text {th }}$ stage nymphs were placed into each cup (12X19X8 $\mathrm{cm}$ ). Bottom sides of ice-cream cups were covered by filter papers which were moisturized by sterile distilled water. Bacillus isolates were incubate on nutrient agar (Difco) at $30 \pm 2^{\circ} \mathrm{C}$ for $24 \mathrm{~h}$. The cells were then harvested with a drigalski spatula and suspended in sterile distilled water. The turbidity of the each bacterial suspension was adjusted to an optical density at $600 \mathrm{~nm}$ (OD600) of 0.7 (108 colony-forming units $\mathrm{ml}^{-1}$, cfu $\mathrm{ml}^{-1}$ ). Spraying application of the bacterial suspension of $\mathrm{Bm}$ isolates at $10^{8} \mathrm{cfu} \mathrm{ml}^{-1}$ were applied to the nymphs. For the spraying application, after the nymphs had been moved on the cups, the suspension culture was used from a distance of $25-30 \mathrm{~cm}$ with a hand held sprayer of $50-\mathrm{ml}$ capacity until the nymph surface was just wetted with very fine droplets. The negative control cups were sprayed with sterile distilled water and incubated at $25 \pm 1^{\circ} \mathrm{C}$ with $70 \pm 5 \%$ relative humidity (RH), 16:8 h light:dark photoperiod for 12 days in a Binder incubator (Model KBWF 240, Germany). Polyethylene sheets were used together with rubber in order to cover the open sides of cups. The causal agents were again re-isolated from dead nymphs according to Cavados et al. (2001) and shown to be identical to the organisms characterized by sequencing of $16 \mathrm{~S}$ rRNA gene. The bioassays were conducted twice, with three replications.

\section{Statistical analysis}

The mortality data of isolates on nymphs of $P$. prasina were corrected using Abbott's formula (Abbott, 1925) and percentages of mycosed insect cadavers were calculated. Due to the limited availability of insect material for experiment, multiple observations were made for each of the dose groups at a series of times after treatment. Since standard probity analysis techniques are not applicable to serial time-mortality data (Throne et al., 1995; Robertson et al., 2007), serial-time mortality data from bioassays were resolved by probit analysis program (PROBIT2-PP, Throne et al. 1995 ) to calculate $50 \%$ lethal time (LT50) and $90 \%$ lethal time (LT90), despite of that this valid method produced high Chi-square and heterogeneity value. In lethal time analysis Log-Probit analysis was considered in abovementioned program. Slopes of regression lines were compared with each other's by their standard errors. Mortality in fourth instar nymphs of $P$. prasina treated with bacterial isolates were compared by one-way analysis of variance (ANOVA) followed by Tukey-Kramer multiple comparison programs were used to separate means (SPSS, Version 21, SPSS Inc., Chicago IL.).

\section{Results and Discussion}

\section{Bacterial isolation}

A total of 26 bacteria were isolated of which $4 B$. megaterium isolates were selected for this study. These isolates, Sa-1, Sa-5, SAk-2 and SAkc-19, having insecticidal activity were selected to base on morphological, physiological and biochemical characteristics of the isolates (Logan and Vos, 2009).

\section{Biochemical characteristics}

Morphological, physiological and biochemical characteristics of the isolates are shown in Table 1. All isolates were Gram-positive, aerobic, rod and motile. After growing on nutrient agar 24-48 $\mathrm{h}$ at $30^{\circ} \mathrm{C}$, the young colonies were $1-2 \mathrm{~mm}$ in diameter, translucent whitish, irregular, smooth, slightly convex and with entire edges. All isolates, Sa-1, Sa-5, SAk-2 and SAkc-19, showed positive results for: 
catalase; deamination of phenylalanine; acid production from sugars such as l-arabinose, dglucose and d-mannitol; hydrolysis of casein, gelatin and starch and negative results for: voges-proskauer test. All these isolates were able to grow in 5\% sodium chloride solutions. All of the isolates were approved to be members of the genus Bacillus by means of classical tests such as the ability to form spores, colony morphology and gram staining. On the basis biochemical diagnostic experiments, the isolates were identified as Bacillus megaterium.

\section{S rRNA gene sequencing}

The 16S rRNA gene fragments of the reference strains applied in the research were achieved from GenBank. The phylogenetic tree established on these sequences revealed close relationships among the isolates and with other members of the genus Bacillus (Figure 1). The generated nucleotide sequences of Sa-1, Sa-5, SAkc-2 and SAkc-19 were received from the GenBank database with accession numbers are KY21924, KY21925, KY231926, KY21927, respectively. Analysis of the $16 \mathrm{~S}$ rRNA gene confirmed that isolates Sa-1, Sa-5, SAk-2 and SAkc-19 are B. megaterium, with $100 \%$ sequence homology to the type strains IAM13418 (KJ569088), ATCC14581 (JF749282), Hd (KY098770), B8 (KU95928) and ARD47 (KX023249) of $B$. megaterium (Figure 1).

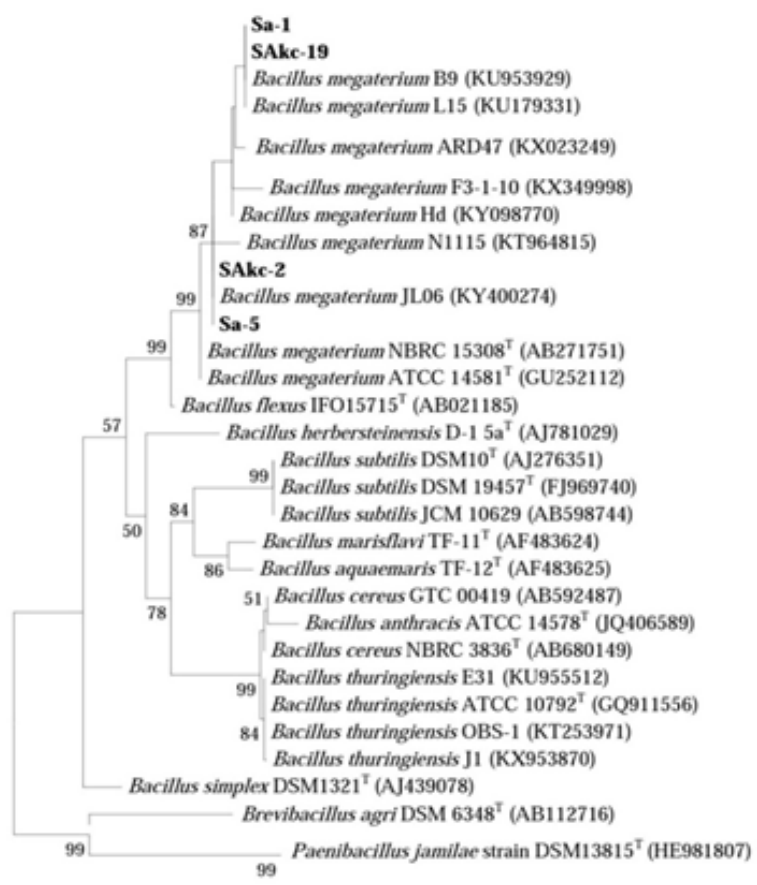

0.02

Figure 1. Maximum Likelihood dendogram based on $16 \mathrm{~S}$ rDNA showing comparison of Bacillus species. Bar=0.02 inferred nucleotide subtitution per nucleotide. Values at nodes indicate bootstrap values for 1000 replicates. Bootstrap values $<50 \%$ were removed. GenBank accession numbers given in the parantheses. Brevibacillus agri and Paenibacillus jamilae were used as an out group, and generated sequences from this study are listed in bold.

Table 1. The morphological, physiological and biochemical characteristics of B. megaterium isolates

\begin{tabular}{|c|c|c|c|c|c|c|}
\hline \multirow[b]{2}{*}{ Parameters } & \multicolumn{4}{|c|}{ Bacillus megaterium isolates } & \multirow{2}{*}{$\begin{array}{l}\text { Lysinibacillus } \\
\text { sphaericus }\end{array}$} & \multirow{2}{*}{$\begin{array}{c}\text { Bacillus } \\
\text { thuringiensis }\end{array}$} \\
\hline & Sa-1 & Sa-5 & SAkc-2 & SAkc-19 & & \\
\hline Shape & Rod & Rod & Rod & Rod & Rod & Rod \\
\hline Gram staining & $\mathrm{G}^{+}$ & $\mathrm{G}^{+}$ & $\mathrm{G}^{+}$ & $\mathrm{G}^{+}$ & $\mathrm{G}^{+}$ & $\mathrm{G}^{+}$ \\
\hline Sporulation & + & + & + & + & + & + \\
\hline Catalase & + & + & + & + & + & + \\
\hline Aerobic growth & + & + & + & + & + & + \\
\hline Voges-Proskauer test & - & - & - & - & - & + \\
\hline $\begin{array}{l}\text { Deamination of } \\
\text { phenylalanine }\end{array}$ & + & + & + & + & + & - \\
\hline Acid from L-Arabinose & + & + & + & + & - & + \\
\hline D-Glucose & + & + & + & + & - & - \\
\hline D-Mannitol & + & + & + & + & - & + \\
\hline Hydrolysis of Casein & + & + & + & + & - & - \\
\hline Gelatin & + & + & + & + & - & + \\
\hline Starch & + & + & + & + & - & + \\
\hline Growth in $5 \% \mathrm{NaCl}$ & + & + & + & + & + & + \\
\hline
\end{tabular}

${ }^{*}(-)$ negative reaction, $(+)$ positive reaction, $(\mathrm{G}+)$ Gram positive

\section{Insecticidal activity}

$\mathrm{LT}_{50}$ and $\mathrm{LT}_{90}$ values of the isolates applied against the nymphs of $P$. prasina were determined by probit analysis. When considering $\mathrm{LT}_{50}$ values of the isolates used, SAkc-2 killed the fastest, with an LT 50 of 1.91 days. The second fastest kill was by Sa-1 isolate with an $\mathrm{LT}_{50}$ of 10.62 days. Except the SAkc-2 isolate, the slopes of the other three isolates were similar. In addition, in terms of $\mathrm{LT}_{90}$ values, the 
fastest effect also occurred in the SAkc-2 isolate with 11.18 days.

At the first day of post treatment there was almost no mortality in any isolates as expected. At the $3^{\text {rd }}$ day of post treatment mortality started to increase rapidly and reached $68 \%$ in SAkc- 2 isolate of $B$. megaterium. From 5 to 12 days after treatment, on one isolate, SAkc-2, mortality rates were between
$82 \%$ and $98 \%$. The highest mortality rate was $98 \%$ which was obtained with the treatment of SAkc-2 isolates with a concentration of $10^{8} \mathrm{cfu} \mathrm{ml}^{-1}$ on the $12^{\text {th }}$ day. The Sa-1, Sa-5 and SAkc-19 isolates caused the lowest insecticidal activity, where the percentage mortalities were ranged between $32 \%$ - 60.0\% at with a concentration of $10^{8} \mathrm{cfu} \mathrm{ml}^{-1}$ on the $12^{\text {th }}$ day (Figure 2).

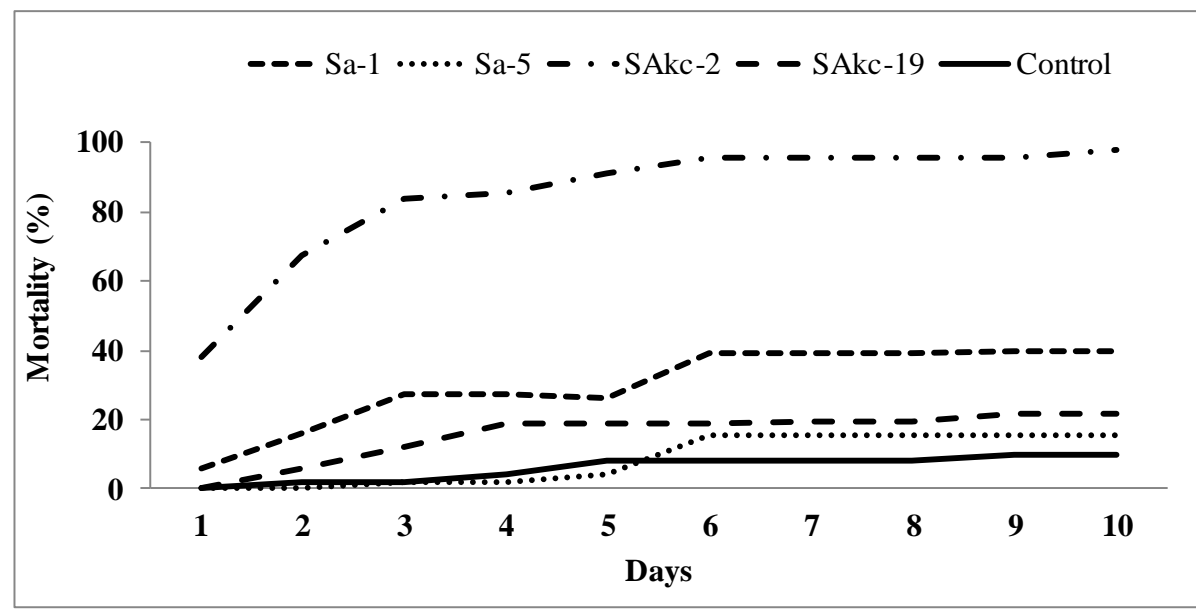

Figure 2. Lethal times ( $\mathrm{LT}_{50}$ and $\mathrm{LT}_{90}$ ) for fourth stage nymphs of Palomena prasina treated with Bacillus megaterium isolates.

The fact that most Bacillus species only differ in one biochemical property makes classical biochemical identification quite difficult at the species level. However, B. megaterium, L. sphaericus and $B$. thuringiensis are distinguished by voges-proskauer; acid production from l-arabinose, d-mannase, $d$ glukoz and d-mannitol; hydrolysis of casein, geletain and starch and deamination of phenylalanine. $B$. megaterium can create acid from hydrolyse casein and d-glucose while L. sphaericus and B. thuringiensis cannot (Sneath, 1986; Slepecky and Hemphill, 2006; Logan and Vos, 2009). In accordance with results of our study, Sa-1, Sa-5, SAk-2 and SAkc-19 were approved to be members of the genus Bacillus by means of classical tests suhc as gram staining, spores and colony morphology. In addition, the results showed that these four isolates, could produce acid from d-glucose and hydrolyse casein. On the basis of biochemical diagnostic tests, the isolates were identified as $B$. megaterium (Table 1 ). The test of the $16 \mathrm{~S}$ rRNA gene verified that isolates Sa-1, Sa-5, SAk2 and SAkc-19 are B. megaterium, with 100\% sequence homology to the type strains of $B$. megaterium (Figure 1).

For many pathogens, Bacillus species are applied as an alternative control agents. For the reason that their capacity to produce toxins during sporulation (Pietrantonio et al., 1993; Zhang et al., 1995; Wagner et al., 1996). Various studies have been done on the nematicidal and insecticidal influences of $B$. megaterium. Khyami-Horani et al. (1999) reported that populations of $B$. megaterium were highly toxic to the $4^{\text {th }}$ instar larvae of Culiseta longiareolata (Diptera: Culicidae). According to Aksoy and OzmanSullivan, (2008) that isolates of B. megaterium were successfully used for Aphis pomi (Hemiptera: Sternorrhyncha: Aphididae), caused $92 \%$ to $100 \%$ mortality within five days of the treatments. In addition, this bacterium has also been applied against pathogenies such as nematodes. According to Neipp and Becker, (1999) that numerous microorganism isolates were succesfully against beet cyst eelworm (Tylenchida: Heteroderidae), reduced J2 penetration of Beta vulgaris. Al-Rehiayani et al. (1999) declared that B. megaterium was successfully applied for Pratylenchus penetrans (Tylenchida: Pratylenchidae) and Meloidogyne chitwoodi (Tylenchida: Heteroderidae), reducing J2 penetration of Solanum tuberosum. Although $B$. megaterium was researched as an alternative biotic control agent for Meloidogyne graminicola (Tylenchida: Heteroderidae) on Oryza sativa 
(Padgham and Sikora, 2007). Crude metabolites produced by $B$. megaterium decreased nematode eggs and numbers of Meloidogyne exigua (Tylenchida: Heteroderidae) (Oliveira et al., 2007). In this study, the results showed that only one isolate, SAkc-2 of $B$. megaterium was highly pathogenic to the fourth instars of $P$. prasina. The median lethal times $\left(\mathrm{LT}_{50}\right)$ for SAkc-2 showed the fastest effect with an $\mathrm{LT}_{50}$ of 1.36 days and the highest mortality rate $98 \%$ after 12 days of post treatment under controlled laboratory conditions, at
$25 \pm 1^{\circ} \mathrm{C}$ and $70 \% \pm 5^{\circ} \mathrm{C} \mathrm{RH}$. On the other hand, the median lethal times $\left(\mathrm{LT}_{50}\right)$ for the other three isolates; Sa-1, Sa-5, SAkc-19 showed very low efficacies, varying from 23.89 to 10.62 days and the total mortality rates varied between $14 \%$ and $60 \%$. In addition, when considering LT90 values, the fastest effect was also occurred in the SAkc-2 isolate within 5.45 days, followed by Sa-1 isolate with 46.97 days, and the others. The Slope $\pm \mathrm{SE}$ and Chi-square values of bioassays are given in table (2) (Table 2, Figure 3).

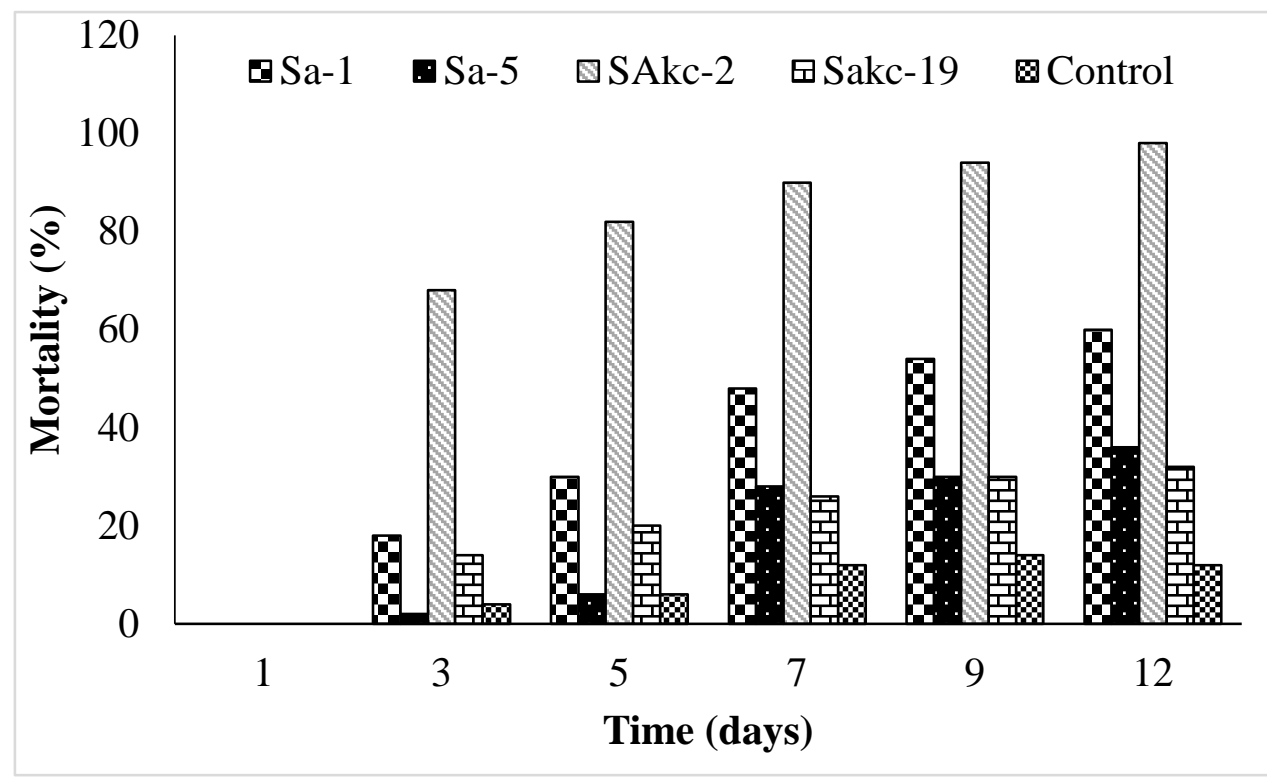

Figure 3. Mortality in fourth stage nymphs of Palomena prasina treated with Bacillus megaterium isolates $(\mathrm{P}<0.05)$.

Table 2 Lethal times ( $\mathrm{LT}_{50}$ and $\mathrm{LT}_{90}$ ) for fourth stage nymphs of Palomena prasina treated with Bacillus megaterium isolates

\begin{tabular}{|c|c|c|c|c|}
\hline Species & $\begin{array}{c}\mathrm{LT}_{50} \\
\text { (95\% fiducial limits) }\end{array}$ & $\begin{array}{c}\mathrm{LT}_{90} \\
\text { (95\% fiducial limits) }\end{array}$ & Slope \pm SE & $\chi^{2}$ \\
\hline Sa-1 & $10.62(7.33-17.85)$ & $46.97(25.46-150.41)$ & $1.98 \pm 0.35 \mathrm{ab}$ & 1.23 \\
\hline Sa-5 & 23.89 (Undefined) & 157.43 (Undefined) & $1.56 \pm 0.38 \mathrm{abc}$ & 14.52 \\
\hline SAkc-2 & 1.36 (Undefined) & 5.45 ( Undefined) & $0.15 \pm 0.03 \mathrm{~d}$ & 150.58 \\
\hline SAkc-19 & $56.35(19.89-1389.47)$ & $925.08(134.49-944962.60)$ & $1.05 \pm 0.31 \mathrm{bc}$ & 3.63 \\
\hline
\end{tabular}

Slopes followed by same letters do not differ significantly.

Our results were consistent with earlier reports indicating the effectiveness of some strains of $B$. megateium, which was determined as entomopathogenic bacterium on different insect and nematodes (Padgham and Sikora, 2007; Aksoy and Ozman-Sullivan, 2008; Huang et al., 2010). It may be possible to use the SAkc- 2 as a potential biocontrol agent against $P$. prasina in quite large hazelnut plantations of Turkey. However, it is also necessary to evaluate the field efficiency of the isolate on $P$. prasina in order to establish a successfully biocontrol program.

\section{Acknowledgements}

This study was supported by Ondokuz Mayis University, Project Management Office with project number of PYO.ZRT.1901.11.004. 


\section{References}

Abbott, W.S., 1925. A method of computing the effectiveness of an insecticide. Journal of Economic Entomology, 18 : 265-267.

Aksoy, H. M., Ozman-Sullivan, S. K., 2008. Isolation of Bacillus megaterium from Aphis pomi (Homoptera: Aphididae) and Assessment of Its Pathogenicity. Journal of Plant Pathology, 90: 433-436.

Al-Rehiayani, S., Hafez, S. L., Thornton, M., 1999. Effects of Pratylenchus neglectus, Bacillus megaterium, and oil radish or rapeseed green manure on reproductive potential of Meloidogyne chitwoodi on potato. Nematropica, 29: 37-49.

Anonymous, 2016a. Findik raporu, Subat 2015, Ankara. T.C. Gümrük ve Ticaret Bakanlığı, Kooperatifçilik Genel Müdürlügü, 29p.

Anonymous, 2016b. 2014 Yılı Fındık sektör raporu. Toprak Mahsulleri Ofisi Genel Müdürlüğü.

Buresova, V., Franta, Z., Kopacek P. 2006. A comparison of Chryseobacterium indologenes pathogenicity to the soft tick Ornithodoros moubata and hard tick Lxodes ricinus. Journal of Invertebrate Pathology, 93: 96-104.

Cavados, C. F. G., Fonseca, R. N., Chaves, Q., Rabinovitch, L., Araujo-Coutinho, C. J. P. C., 2001. Identification of entomopathogenic Bacillus isolated from Simulium (Diptera, Simuliidae) larvae. Memorias Instituto Oswaldo Cruz, 96: 1017-1021.

Gokce, C., Sevim, A., Demirbag, Z., Demir I. 2010. Isolation, characterization and pathogenicity of bacteria from Rhynchites bacchus (Coleoptera: Rhynchitidae). Biocontrol Science and Technology, 20: 973-982.

Gu, Y. Q., Zhou, J. P., Mo, M. H., Zhang, K. Q., 2007. Evaluation and identification of potential organic nematocidal nematocidal volatiles from soil bacteria. Soil Biology and Biochemistry, 39: 25672575 .

Huang, Y., Ma, L., Xu, C., Zhang, K., Duan, C., Mo, M. 2010. Characterisation of volatiles produced from Bacillus megaterium YFM3.25 and their nematicidal activity against Meloidogyne incognita. European Journal of Plant Pathology, 126: 417-422.

Khyami-Horani, H., Katbeh-Bader, A., Mohsen, Z. H. 1999. Isolation of endospore-forming bacilli toxic to Culiseta longiareolata (Diptera: Culicidae) in Jordan. Letters in Applied Microbiology, 28: 57-60.

Logan, N. A., Vos, D. P. 2009. Genus I. Bacillus Cohn 1872. In: The Firmicutes, Bergey's Manual of Systematic Bacteriology 2nd ed 3:21-128, Springer, New York, NY, USA.
Neipp, P. W., Becker, J. O., 1999. Evaluation of biocontrol activity of rhizobacteria from Beta vulgaris against Heterodera schachtii. Journal of Nematology, 31: 54-61.

Oliveira, D.F., Campos, V.P., Amaral, D.R., Nunes, A.S., Pantaleo, J.A., Costa, D.A. 2007. Selection of rhizobacteria able to produce metabolites active against Meloidogyne exigua. European Journal of Plant Pathology, 119: 477-479.

Ozsahin, E., Sezen, K., Demir, I., Demirbag Z., 2014. Bacterial isolates from Palomena prasina (Hemiptera: Pentatomidae) include potential microbial control agents. Biocontrol Science and Technology, 24: 1039-1051.

Padgham, J. L., Sikora, R. A., 2007. Biological control potential and modes of action of Bacillus megaterium against Meloidogyne graminicola on rice. Crop Protection, 26: 971-977.

Patricia, S. V., Biedendieck, R., Fuerch, T., Meinhardt F., Rohde, M., Deckwer, W. D., Jahn, D., 2007. Bacillus megaterium-from simple soil bacterium to industrial protein production host. Applied Microbiology and Biotechnology, 76: 957-967.

Pietrantonio, P. V., Federici, B. A., Gill, S. S., 1993. Interaction of Bacillus thuringiensis endotoxin with the insect midgut epithelium. In: Beckage $\mathrm{N}$., Thompson, S. N., Federici, B. A. (eds.). 1: 55-79. Parasites and Pathogens of Insects. Academic Press, New York, NY, USA.

Robertson, J. L., Russell, R. M., Preisler H.K., Savin, E., 2007. Bioassays with Arthropods $2^{\text {nd }}$ Edn. CRC Press, Boca Raton, FL (US).

Sezen, K., Demir, I., Demirbag, Z., 2004. Study of the bacterial flora as a biological control agent of Agelastica alni L. (Coleoptera: Chrysomelidae). Biologia, 59: 327-331.

Slepecky, R. A., Hemphill, H. E., 2006. The Genus BacillusNonmedical. Prokaryotes, 4: 530-562.

Sneath, P. H. A. 1986. Endospore-forming gram positive Rods and Cocci. 1104-1105 In: Sneath, P. H. A., Mour N. S., Sharpe M. E., Holt J. G. (eds). Bergy's Manual of Systematic Bacteriology 8th Edition William \& Wilkins Baltimore.

Tamura, K., Stecher, G., Peterson, D., Kumar, S. 2013. MEGA 6:Molecular Evolutionary Genetics Analysis Version 6.0. Molecular Biology Evolution, 30:2725-2729.

Tavella, L., Arzone, A. M., Miaja, L., Sonnati, C. 2001. Influence of Bug (Heteroptera, Coreidae and Pentatomidae) feeding activity on hazelnut in Northwest Italy. Acta Horticulturae, 556: 461-468. 
Throne, J. E., Weaver, D. K., Chew, V., Baker, J. E., 1995. Probit analysis of correlated data: Multiple observations over time at one concentration. Journal of Economic Entomology, 88: 1510-1512.

Tuncer, C., Akça, I., Saruhan, I. 2002. Findikta zararlı olan bazı emici boceklerin (Heteroptera: Pentatomidae, Coreidae ve Acanthosomatidae) kimyasal mucadelesi uzerine arastirmalar. Ondokuz Mayis Universitesi Ziraat Fakultesi Dergisi, 17: 17-26.

Tuncer, C., Saruhan, I., Akca, I. 2004. The Insect Pest Problem Affecting Hazelnut Kernel Quality in Turkey. 6. International Hazelnut Congress. Tarragona, Spain, 14-18 June 2004.

Tuncer, C., Saruhan, I., Akca, I. 2005. The Insect Pest Problem Affecting Hazelnut Kernel Quality in Turkey. Acta Horticulturae, 668: 367-376.
Tuncer, C., Saruhan I., Akca I. 2009. Chemical Control of True Bugs (Heteroptera: Pentatomidae, Acanthosomatidae and Coreidae) For Preventing Kernel Damage in Hazelnut Orchards of Turkey. Acta Horticulturae, 845: 487-494.

Wagner, D. L., Peacock, J. M., Carter J.L., Talley, S. E. 1996. Field assessment of Bacillus thuringiensis on nontarget Lepidoptera. Environmental Entomology, 25: 1444-1454.

Weisberg, W. G., Barns, S. M., Pelletier, D. A., Lane, D. J. 1991. 16S ribosomal DNA amplification for phylogenetic study. Journal of Bacteriology, 173: 697-703.

Zhang, H., Deng, W., Yu, Z. 1995. A review on the progresses of controlling stored product insects with Bacillus thuringiensis. Chinese Journal of Biological Control, 11: 178-182. 